\title{
Implementation of the 2013 Curriculum Based on a Scientific Approach (Case Study at SD Cluster II Kintamani)
}

\author{
I Gst A A Wulandari ${ }^{1}$ \\ ${ }^{1}$ Program Studi Pendidikan Guru Sekolah Dasar Universitas Pendidikan Ganesha, Singaraja, Indonesia.
}

\author{
A RTI C LEINFO \\ Article history: \\ Received 2 Juni 2020 \\ Received in revised form \\ 12 Juli 2020 \\ Accepted 10 Agustus 2020 \\ Available online 28 Agustus \\ 2020 \\ kata kunci: \\ Kurikulum 2013, \\ Pendekatan Saintifik, \\ Sekolah Dasar. \\ keywords: \\ 2013 curriculum, scientific \\ approach, elementary \\ school.
}

\begin{abstract}
A B S T R A K
Perubahan kurikulum sering terjadi di dunia pendidikan, seperti yang kita ketahui kurikulum yang digunakan saat ini pada satuan pendidikan adalah kurikulum 2013. Dengan adanya perubahan kurikulum guru seharusnya mengetahui point-point penting dalam kurikulum 2013 yakni: (1) pengetahuan tentang kurikulum 2013; (2) keterampilan merancang perangkat pembelajaran kurikulum 2013; (3) keterampilan mengimplementasikan kurikulum 2013. Maka dari itu, penelitian ini bertujuan untuk menganalisis: pemahaman guru-guru wali kelas SD di Gugus II Kintamani mengenai implementasi kurikulum 2013 berbasis pendekatan saintifik, keterampilan guru-guru wali kelas dalam menyusun RPP kurikulum 2013 berbasis pendekatan saintifik, dan keterampilan guruguru wali kelas dalam menerapkan RPP kurikulum 2013 berbasis pendekatan saintifik. Penelitian ini menggunakan pendekatan kualitatif deskriptif. Penelitian ini dilaksanakan dengan melibatkan 9 orang guru wali kelas di Gugus II Kintamani. Data dalam penelitian ini dikumpulkan menggunakan metode wawancara, studi dokumentasi, dan observasi. Data dianalisis menggunakan teknik reduksi data dan verifikasi data dilakukan
\end{abstract} terhadap responden dan bukti dokumen. Hasil dari penelitian ini menunjukan bahwa guru-guru wali kelas gugus II Kintamani paham dan mampu merancang RPP kurikulum 2013 berbasis pendekatan saintifik namun tidak semua guru mampu mengimplementasikannya dengan baik. Sesuai hasil penelitian tersebut maka dibutuhkan pendampingan berkelanjutan agar penerapan kurikulum 2013 berbasis pendekatan saintifik dapat dilakukan dengan baik oleh guru.

\begin{abstract}
A B S T R A C T
Curriculum changes often occur in the world of education, as we know that the current curriculum used in education units is the 2013 curriculum. With the change in the curriculum, teachers should know the important points in the 2013 curriculum, namely: (1) knowledge of the 2013 curriculum; (2) skills in designing the 2013 curriculum learning tools; (3) the skills to implement the 2013 curriculum. Therefore, this study aims to analyze: the understanding of elementary school homeroom teachers in Cluster II Kintamani regarding the implementation of the 2013 curriculum based on a scientific approach, the skills of homeroom teachers in preparing the 2013 curriculum lesson-based approach scientific, and the skills of homeroom teachers in applying the 2013 curriculum lesson plan based on the scientific approach. This research uses a descriptive qualitative approach. This research was conducted by involving 9 homeroom teachers in Gugus II Kintamani. The data in this study were collected using the interview method, documentation study, and observation. Data were analyzed using data reduction techniques and data verification was carried out on respondents and documentary evidence. The results of this study indicate that the homeroom teachers of Kintamani cluster II understand and are able to design the 2013 curriculum lesson plan based on a scientific approach, but not all teachers are able to implement it properly. According to the results of this study, continuous assistance is needed so that the implementation of the 2013 curriculum based on a scientific approach can be carried out properly by teachers.
\end{abstract}

\section{Introduction}

The Ministry and Culture of the Republic of Indonesia has made various efforts to improve development and the quality of education. One of them is developing a national education curriculum, namely the 2013 curriculum, which began to be implemented in 2013 in certain regions and currently applies to all regions in Indonesia. As an education practitioner, of course the term curriculum is not a new thing that is often discussed, curriculum development in Indonesia continues to experience changes. This happens because of the development of world science and technology, as well as the demands of the Indonesian people who want quality human resources. The 2013

Copyright (C) Universitas Pendidikan Ganesha. All rights reserved. 
curriculum is a series of improvements to the curriculum that was initiated in 2004 which is competency-based and then continued with the KTSP curriculum. Kurukulum is designed to provide the broadest learning experience to develop attitudes, knowledge and skills for these abilities. The results of learning experiences are student learning outcomes that describe humans with the qualities stated in the SKL. The 2013 curriculum defines the Graduate Competency Standards (SKL) as they should be, namely as a criterion regarding the qualifications of graduation abilities including attitudes, knowledge and skills (Meliawati et al., 2015; Subadi et al., 2013). In its application, the 2013 curriculum emphasizes competence with competency thinking based on attitudes, knowledge and skills, and the 2013 curriculum is suitable for elementary school children because the themes are interesting and interrelated. All subjects are theme based and adapted to the subjects being taught (Pangandosan, 2018; Rostika, D \& Zulkarnain, 2016). Learning in the 2013 curriculum does not only emphasize the development of knowledge, thinking skills, and skills acquired through observing, questioning, trying, reasoning, and communicating activities. However, besides that it is also expected to have an accompanying impact on students on the values and attitudes contained in KI-1 and KI-2 (Fahdarani, 2015; Kurniasari, 2017). The most basic characteristic of the 2013 curriculum is it demands the ability of teachers to be knowledgeable and find out as much knowledge as possible because today's students have easily searched for information freely through the development of technology and information (Hidayati, 2019; Makaborang, 2019). The aim of the 2013 curriculum is to develop the potential of students to become human beings who believe and have faith in God Almighty, have noble character, are healthy, knowledgeable, capable, creative, independent, and become democratic and responsible citizens. To achieve this, it is necessary to do the teacher's mindset in the student-centered learning assessment process, be creative in designing learning innovations and developing student creativity and potential, therefore the curriculum is used as an idea / ideas that are translated into a written plan (syllabus / RPP) and then implemented in a manner actual in the learning process (Azizah, 2019; Wahyuni \& Kurniawan, 2019).

The current curriculum in Indonesia is the 2013 Curriculum which is the 2013 Curriculum which emphasizes pedagogical competence in learning using a scientific approach (Scientifical Approach). The scientific approach is a scientific approach, which is designed in such a way that students actively hone competence in attitudes, knowledge and skills through the stages of observing (to identify or find problems), formulate problems, promote or formulate hypotheses, collect data with various techniques, analyze data, draw conclusions and communicate concepts (Abhyasari et al., 2020; Fahreza, 2005; Halimah, 2017). The learning process with a scientific approach touches three domains, namely attitudes, knowledge and skills (Nurbaya et al., 2018; Rudyanto, 2016). The scientific approach uses several strategies such as contextual learning. The scientific approach is intended to provide understanding to students to know, understand, practice what is being studied scientifically. Therefore, in the learning process students are taught to find out from various sources through observing, questioning, gathering information, reasoning and communicating for all subjects (Candra \& Masruri, 2015; Persada et al., 2020). Learning with the scientific method has the following characteristics: 1) student-centered; 2) involving scientific process skills and constructing concepts, laws or principles; 3 ) involving cognitive processes that have the potential to stimulate intellectual development, especially students' higher order thinking skills; 4) can develop character (Hapsari et al., 2019; Yustitia et al., 2018). Important components in teaching using a scientific approach include: 1) presenting learning that can increase curiosity; 2) improve observing skills; 3) perform analysis; 4) communicate (Said et al., 2019; Wakhidah, 2019). (Nurdyansyah \& Fahyuni, 2016; Yanwar \& Fadila, 2019) states the steps of learning with a scientific approach through five learning experiences, namely observing, asking (questioning), gathering information / trying (experimenting), reasoning / associating (associating), and communicating (communicating). So, it can be concluded that this approach is used in learning with an emphasis on the use of scientific methods in learning activities. This is based on the essence of learning which is actually a scientific process carried out by students and teachers. The scientific approach is the basis for learning the 2013 curriculum because there are efforts to improve the quality of students' thinking. Through the scientific approach students are not only trained to develop thinking and reasoning skills, but also develop other aspects of students in learning. The learning process with a scientific approach must touch three domains, namely attitudes, knowledge, and skills. The end result is an increase and balance between the ability to become good humans (soft skills) and humans who have the skills and knowledge to live properly (hard skills) from students which include aspects of competence in attitudes, skills, and knowledge.

The implementation of the 2013 curriculum is very important to improve the quality of education. In order to prepare a complete and comprehensive implementation of the 2013 curriculum, every school should be able to optimally develop various potentials of students, 
especially in character and moral development (Makaborang, 2019; Pujiyanto, 2013). The most important component in implementing the 2013 curriculum is the implementation of the learning process both inside / outside the classroom to achieve competency in the knowledge, attitudes and skills of students (Ibrahim et al., 2019; Subadi et al., 2013). To achieve the implementation of the 2013 curriculum learning process, appropriate teaching methods are used. The teaching methods used in the 2013 curriculum are tailored to the characteristics of students and subjects. Among them are scientific / scientific methods, inquiry, problem-based learning and project-based learning in all subjects. In addition, other approaches / methods can be applied, namely contextual learning and cooperative learning (Fadliyatis et al., 2016; Rostika, D \& Zulkarnain, 2016). The teacher is a determining factor in implementing the 2013 curriculum, so the teacher must know about the 2013 curriculum, know the assessment in the 2013 curriculum, be skilled in designing learning, and be able to apply it (Nugraheni, 2019)(Sugiyanto et al., 2015). Based on this description, a teacher plays an important role in implementing the curriculum in schools, with changes in the curriculum, teachers are required to be updated with developments in the world of education. With the change in the curriculum, teachers should understand 3 important points about the 2013 curriculum, namely: (1) knowledge of the 2013 curriculum, (2) skills in designing learning tools for the 2013 curriculum, and (3) skills in implementing the 2013 curriculum. The 2013 curriculum has indeed been implemented for 5 years ago, one of them was in Cluster II Kintamani. In this cluster, the implementation of the 2013 curriculum has been carried out for 2 years ago by taking 2 pilot schools, namely SD N 1 Batur and SD N 2 Batur. Since the new school year last year all schools in Gugus II Kintamani have implemented it simultaneously, namely SD N 1 Batur, SD N 2 Batur, SD N 3 Batur, and SD N 4 Batur, and SD N 5 Batur, and SD N 6 Batur, and SD N 7 Batur.

The analysis activity of the 2013 curriculum application based on the scientific approach is useful as a track record of the learning process that took place before. The relevant research conducted by researchers prior to the analysis of the 2013 curriculum implementation is research by 1) Kurniawan \& Fatonny (2016) stated that with an operating system with a scientific approach, the public can get information about thematic themes 4 and 5 via cellphones. 2) Muharmiati et al., (2020) stated that the teacher had carried out scientific activities in the 2013 curriculum but it was not optimal. 3) Zaman (2017) stated that in the implementation of the scientific approach to science learning the teacher had done it according to the procedure. 4) Budiyanto et al., (2016) stated that the implementation of the scientific approach in SD Malang has been carried out by the teacher according to the learning steps.

The general purpose of this study is to analyze the understanding and skills of elementary school teachers in Cluster II Kintamani in implementing the 2013 Curriculum using a scientific approach.

\section{Research Method}

The type of research used is descriptive qualitative because the results of this study present the information from the work analysis in the form of the 2013 curriculum application based on a scientific approach in elementary schools. Qualitative methods are used to reveal natural or natural objects and the researcher as the instrument. The resulting data is descriptive data in the form of written words produced directly by the researcher. The place of this research is Cluster II Kintamani with research subjects involving 9 teachers. The research data is in the form of information on the implementation of the 2013 curriculum based on the scientific approach carried out by the teacher. The data collection techniques used are as follows:

Table 01. Data Collection Techniques

\begin{tabular}{llll}
\hline No & \multicolumn{1}{c}{ Research Problems } & $\begin{array}{c}\text { Data Collection } \\
\text { Technique }\end{array}$ & Data source \\
\hline $1 \quad$ & $\begin{array}{l}\text { What is the understanding of elementary school } \\
\text { homeroom teachers in Cluster II Kintamani } \\
\text { regarding the implementation of the 2013 } \\
\text { curriculum based on a scientific approach? }\end{array}$ & $\bullet$ & Interview \\
& $\begin{array}{l}\text { What are the skills of homeroom teachers in } \\
\text { preparing the } 2013 \text { curriculum lesson plans based } \\
\text { on a scientific approach? }\end{array}$ & $\bullet \quad \begin{array}{l}\text { Document } \\
\text { study }\end{array}$ & $\bullet$ Syllabus, \\
RPP
\end{tabular}


3 What are the skills of homeroom teachers in applying the 2013 curriculum lesson plan based on a scientific approach

Based on the table above, it is known that the data collection techniques used were document studies, questionnaires, and interviews. The following is a more specific explanation of the data collection methods and instruments.

a) Interview

The words or actions of the people being observed or interviewed are the main source of data. The main data sources are recorded through written notes or through recording video / audio tapes, taking photos or films (Moleong, 2006:157). The type of interview used in this study is an open standard interview, this type of interview uses standard questions. The order of the questions, the words, and the way they are presented are the same for each respondent (Moleong, 2006:188).

Data collection using interviews was conducted with the aim of extracting information about teacher knowledge in the implementation of the 2013 curriculum with a scientific approach.

b) Studi dokumen

This data collection technique was intended to verify the data that the researcher had previously obtained during the interview. The suitability between the answers during the interview with the supporting documents owned by the teacher, namely the RPP.

c) Observasi

According to Agung (2014:94) that "observation is a way to make direct and systematic observations". The advantage of the observation method is that the results are more accurate and difficult to argue with. The observation method developed was in the form of an observation activity sheet for the implementation of the 2013 curriculum lesson plan using a scientific approach.

Based on this explanation, the data collected is then analyzed qualitatively where the data taken by interviewing techniques, document study, and observation will be described. The steps that will be taken before the data are analyzed are data reduction, data classification and analysis, and drawing conclusions or data verification.

\section{Result and Discussion}

Based on the results of research conducted through interviews, document study, and observations with predetermined informants, the general findings of this study are that Kintamani class II homeroom teachers understand and are able to design RPP curriculum 2013 based on a scientific approach, but not all teachers are able to implement it with well.

The special findings of the research results provide an overview of the implementation of the 2013 curriculum using a scientific approach, which includes:

First: The teacher's understanding of the implementation of the 2013 curriculum using a scientific approach is quite good. These results were obtained through intensive interviews conducted by researchers with teachers, researchers prepared 10 questions related to the 2013 curriculum, then asked each question to all research subjects in turn. The first teacher managed to answer 7 questions correctly, although a little haltingly, but the first teacher included understanding what the 2013 curriculum was like. The second teacher was also given the same questions, but was only able to answer 6 questions, even though only 6 out of 10 were answered. questions but half of them were answered so that the second teacher also understood what the 2013 curriculum was like. The interview was then continued with teacher 3 , teacher 4 , teacher 5 , teacher 6 , teacher 7 , teacher 8 , and teacher 9 the results were not much different from the previous teachers all the teachers managed to answer at least 6 questions out of 10 questions, even a teacher managed to answer all the questions correctly. So, it can be concluded that the teacher's understanding of the implementation of the 2013 curriculum using the scientific approach is quite good. A summary of the results of the interview can be seen in the following table. 


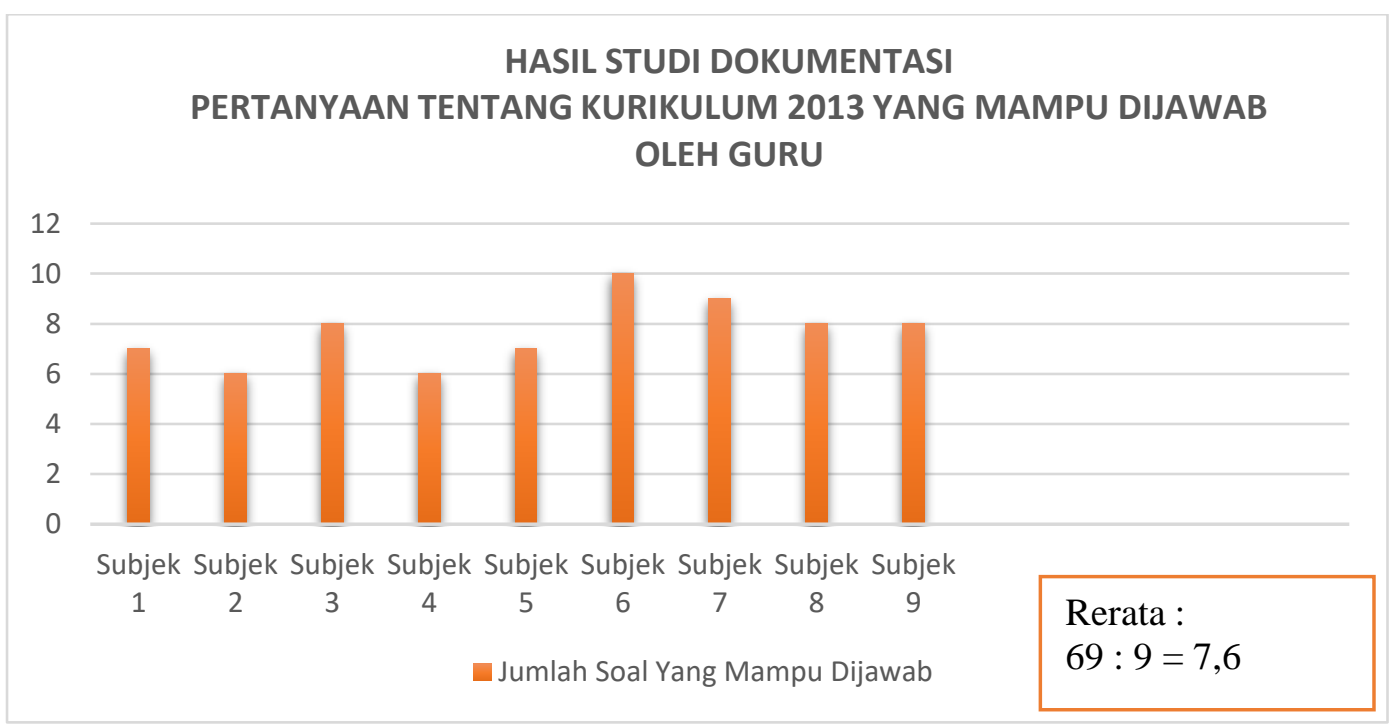

Figure 01. Diagram of the results of the Documentation study

These results indicate that the level of knowledge of SD Gugus II Kintamani teachers about the implementation of the curriculum is classified as good because it is at an average of 7.6. So that with this knowledge capital, teachers should be able to implement the 2013 curriculum well. This is also in line with the results of research conducted by (Makaborang, 2019; Rini Kristiantari, 2015) which states that the category of teachers who understands the 2013 curriculum is at a very high level, this means that teachers have sufficient understanding of the application of the 2013 curriculum.

This knowledge and understanding is the initial capital to be able to implement a policy so that if someone has adequate knowledge, of course, he can apply the policy well. In accordance with the understanding of the curriculum previously described, the curriculum is a collection of ideas / ideas, so that a teacher who has a good understanding of the curriculum should be able to develop the curriculum according to his / her ideas.

Second: The skills of homeroom teachers in preparing the 2013 curriculum lesson plans based on the scientific approach are quite good. These results were obtained through the study of RPP documentation, the indicators for assessing the lesson plans that were carried out were (1) the lesson plans had shown certain themes, (2) core competencies were already included in the lesson plans, (3) learning activities had used a scientific approach (observing, asking questions, collecting information, reasoning, and communicating). This documentation study procedure is carried out by asking each teacher to show an example of the lesson plan used in daily learning then the researcher uses a checklist sheet to assess the lesson plan that the teacher has made, the results of the checklist can be seen in the following table.

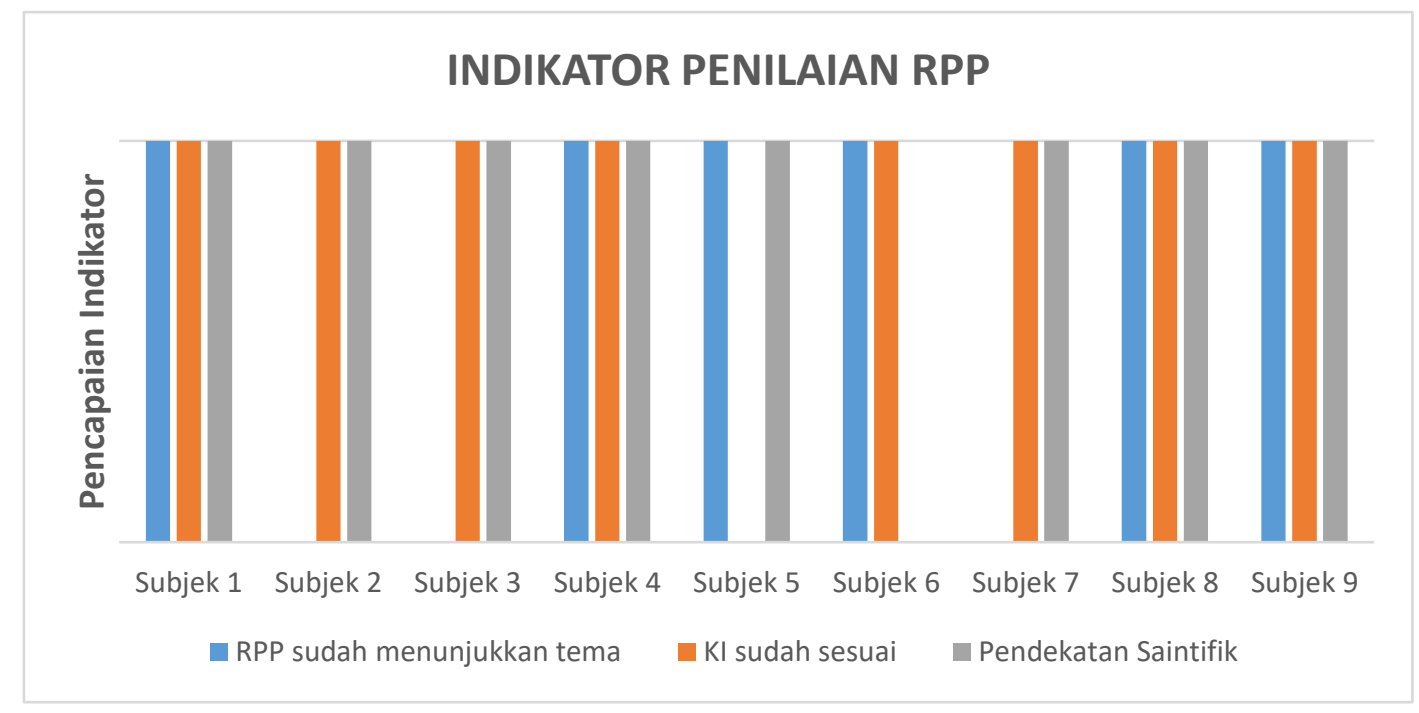

Figure 02. Results of the Teacher RPP Documentation Study 
Based on the table, it is known that each teacher has met at least 2 assessment indicators, even 4 teachers have met all three indicators, this indicates that the teacher is skilled in designing learning activities that are in line with the 2013 curriculum using a scientific approach. So it can be concluded that the skills of homeroom teachers in compiling 2013 curriculum lesson plans based on a scientific approach are good enough.

These results indicate that the teachers of SD Gugus II Kintamani are able to properly prepare the 2013 curriculum lesson plans using a scientific approach. This is certainly supported by the adequate knowledge they have about the 2013 curriculum. As previously explained, the curriculum is an idea that has been planned and written in a learning tool (Syllabus / RPP). So that this written plan should be able to be implemented in accordance with the previously made plans.

This is also in line with research conducted by (Candra \& Masruri, 2015; Meliawati et al., 2015) which states that the teacher has been able to compile a lesson plan in accordance with the demands of the 2013 curriculum which is characterized by the lesson plan made in accordance with the principles of developing lesson plans, and the learning activities are scientific.

Third: The skills of homeroom teachers in implementing the 2013 curriculum lesson plan based on the scientific approach are not good enough. Unlike the two previous problems that were answered well, the third problem was answered badly. These results were obtained through observations of teaching and learning activities carried out by researchers to the nine teachers in the class. The following is a table of observations made by researchers.

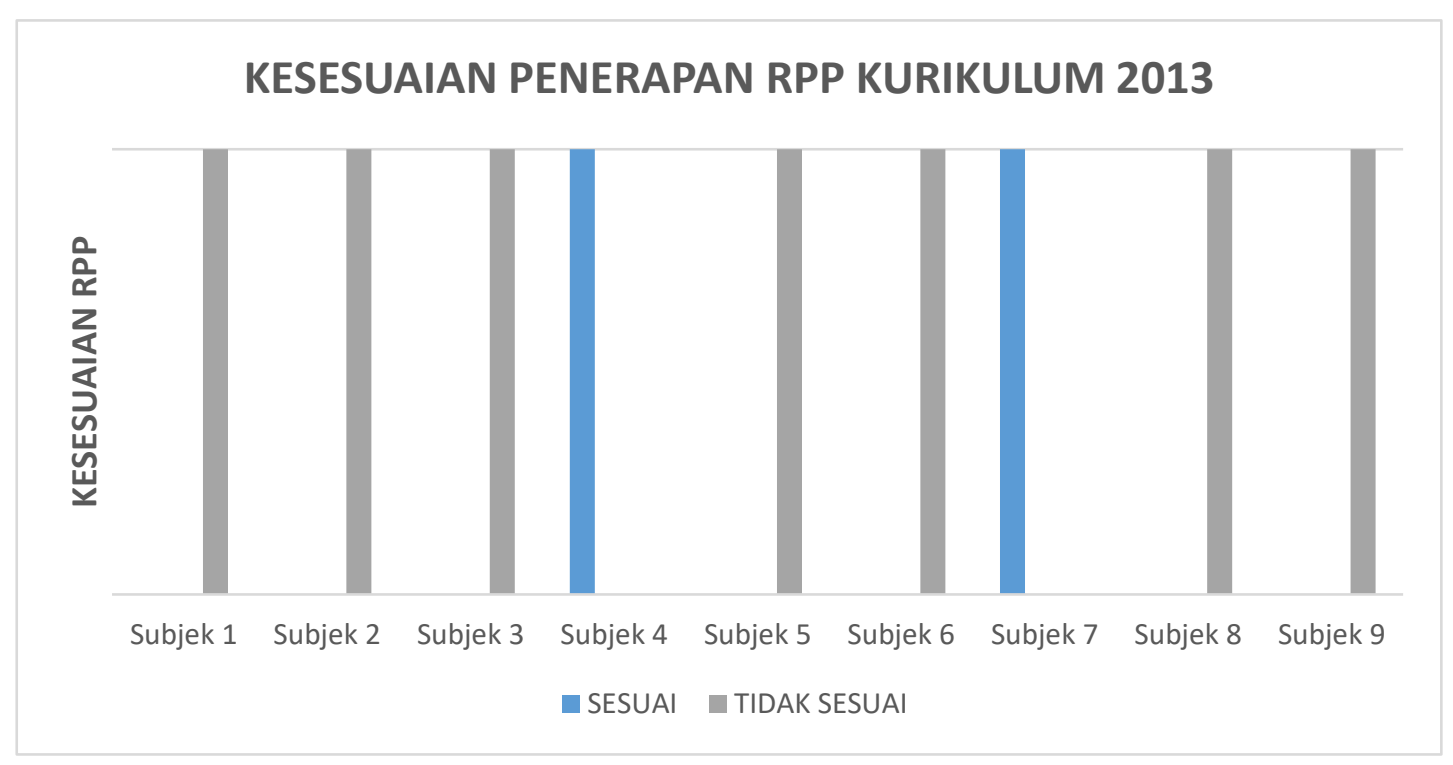

Figure 03. Observation Results Diagram for the Implementation of the 2013 Curriculum RPP

Looking at the diagram, it can be seen that only 2 teachers were able to implement what was planned in the lesson plan properly. This can be seen from (1) the learning activities are according to the theme and flow into one inseparable unit, (2) they have used a scientific approach. This is very different from the other seven teachers, one of which is subject 9 at that time learning the theme of my family, (1) the teacher does not completely relate the material to my family theme, he just explains the material just like that, (2) teaches students such as teaching subject areas, still visible which is mathematics, which is Indonesian, which is ips. Even when the researcher observes the full learning activity from start to finish, it is very clear that the subject restrictions are carried out by the teacher. Other teachers did not even apply a scientific approach to learning, even though in the lesson plans he wrote it was clear what learning activities required observation, reasoning, asking questions, gathering information, and informing, but the real activities carried out were only limited to lectures, questions and answers, assignments. So it can be concluded that the skills of homeroom teachers in implementing the 2013 curriculum lesson plan based on the scientific approach are not good enough.

Researchers identified several reasons for teacher skills in implementing the 2013 curriculum that were not in accordance with the policies set by the government, including: (1) teachers were not accustomed to using integrative thematic so that learning still appeared separate between subjects, (2) teachers were not free to use the scientific approach because of this approach still classified as new to the teachers. Based on the results of the analysis carried out, the teachers understood the 2013 curriculum and the scientific approach, but in practice they were still not used 
to it. So not all teachers are able to apply the 2013 curriculum based on a scientific approach. This is in line with research by (Ula, 2015) stated that the planning of learning in the 2013 curriculum with a scientific approach was not mature. Further research by (Ashri, 2017) stated that in the implementation of the 2013 curriculum based on a scientific approach, the readiness of teachers to plan, implement and follow up on learning there were still several obstacles. Research by (Masita, 2015) stated that thematic learning with a scientific approach in the learning process was not optimal, because the teacher was still the controlling center while the students were passive. Research by Mirnasulistiawati states that in the implementation of the curriculum it is very possible that there will be differences between planning and reality that are local and contextual. Research by Yeti (2017) states that the implementation of the scientific approach to language learning has been carried out, but in the questioning aspect not all students are actively involved.

\section{Conclusion}

Based on the results of the research that has been carried out, it can be concluded that the importance of implementing the 2013 curriculum based on a scientific approach in the learning process, this is because the scientific approach uses a scientific and contextual approach in learning. In addition, in the scientific approach, students go through five learning experiences and require students to be actively involved in the learning process. Therefore, the role of teachers in implementing the 2013 curriculum based on a scientific approach is very important. Because the teacher is the determining factor for the success of learning and the curriculum itself. Curriculum planning in the teaching process is also very necessary, planning learning tools must of course be in line with the learning taking place. Based on the results of the analysis, it was concluded that the homeroom teachers of Kintamani cluster II understood and were able to design the 2013 curriculum lesson plan based on a scientific approach, but not all teachers were able to implement it properly. According to the results of this study, continuous assistance is needed so that the implementation of the 2013 curriculum based on a scientific approach can be carried out properly by teachers.

\section{References}

Abhyasari, N. P., Kusmariyatni, N. N., \& Agustiana, I. G. A. T. (2020). Pengaruh Pembelajaran Berpendekatan Saintifik Berbasis Masalah Terhadap Disiplin dan Hasil Belajar IPA. Mimbar PGSD Undiksha, 8(1), 111-122.

Agung, A. A. G. (2014). Metodelogi Penelitian Pendidikan. Aditya Media Publishing.

Ashri, A. N. (2017). Analisis Kesiapan Guru Dalam Implementasi Kurikulum 2013 Berdasarkan RPP Tahun 2014 SD Muhammadiyah 21 Baluwarti DI. Ekp, 13(3), 1576-1580.

Azizah, R. (2019). Implementasi kurikulum 2013 pada mata pelajaran tematik (studi kasus di mi ma'arif patihan wetan ponorogo). Institut Agama Islam Negeri Ponorogo.

Budiyanto, K., Waluyo, L., \& Mokhtar, A. (2016). Implementasi Pendekatan Saintifik dalam Pembelajaran di Pendidikan Dasar di Malang. Proceeding Biology Education Conference, 13(1), 46-51.

Candra, A. A., \& Masruri, M. S. (2015). Pengembangan Multimedia Interaktif Dengan Pendekatan Saintifik Untuk Pembelajaran PKn SMP. Harmoni Sosial: Jurnal Pendidikan IPS, 2(2), 109-144. https://doi.org/https://doi.org/10.21831/hsjpi.v2i2.7662

Fadliyatis, K. S., Harsiati, T., \& Hasanah, M. (2016). Pengembangan Instrumen Asesmen Autentik Keterampilan Menulis Teks Cerpen Dan Teks Fabel Untuk Siswa Smp / Mts. Jurnal Pendidikan, 1(3), 421-427. https://doi.org/http://dx.doi.org/10.17977/jp.v1i3.6168

Fahdarani, R. R. (2015). Implementasi pendekatan saintifik pada kurikulum 2013 di kelas 4 sdn cijantung 03 pagi. Universitas Islam Negeri Syarif Hidayatullah.

Fahreza, F. (2005). Analisis Penerapan Pendekatan Saintifik Di SD Se-Kecamatan Binjai Utara Kota Binjai. Naspa Journal, 42(4), 1. https://doi.org/10.1017/CB09781107415324.004

Halimah, L. (2017). Keterampilan Mengajar. Refika Aditama.

Hapsari, E. E., Sumantri, M. S., \& Astra, I. M. (2019). Strategi Guru Meningkatkan Hasil Belajar Menggunakan Pendekatan Saintifik Di Sekolah Dasar. Jurnal Basicedu, 3(2), 850-860. 
https://doi.org/10.31004/basicedu.v4i4.445

Hidayati, W. N. (2019). Penerapan Pendekatan Saintifik Pada Pembelajaran IPA Kelas V DI MI Islamiyah Kroya Tahun Pelajaran 2017/2018 Skripsi (Vol. 53, Issue 9) [Institut Agama Islam Negeri (IAIN) Purwokerto]. https://doi.org/10.1017/CB09781107415324.004

Ibrahim, Ridwan, \& Arifin. (2019). Implementasi Kurikulum 2013 Untuk Meningkatkan Kualitas Pendidikan di Indonesia ( Kajian Proses Pembelajaran K-13 di Kota Tarakan dan Kabupaten Bulungan Kalimantan Utara ). Borneo Journal Of Biology Education, 1(1), 74-81.

Kurniasari, F. (2017). Implementasi Pendekatan Saintifik Pada Penugasan Aktivitas Di Buku Teks Bahasa Indonesia Kelas VII SMP Berdasarkan Kurikulum 2013. Jurnal Pendidikan Edutama, 4(1), 9-26. https://doi.org/http://dx.doi.org/10.30734/jpe.v4i1.44

Kurniawan, \& Fatonny, M. (2016). Perangkat Lunak Ajar Dengan Pendekatan Saintifik Kurikulum 2013 Berbasis Android (Studi Kasus Tematik 4 Tema 5). Jurnal Informatika, 5(1), 64-71.

Makaborang, Y. (2019). Evaluasi Implementasi Kurikulum 2013 Mata Pelajaran Biologi Di SMA Negeri. Kelola: Jurnal Manajemen Pendidikan, 6(2), 130-145. https://doi.org/10.24246/j.jk.2019.v6.i2.p130-145

Masita, D. (2015). Pembelajaran Tematik Dengan Pendekatan Saintifik Dalam Implementasi Kurikulum 2013 (Studi Multi Kasus di SDN Turen 03 Kecamatan Turen dan MIT Ar-Roihan Kecamatan Lawang Kabupaten Malang) (Vol. 2013).

Meliawati, N. W., Suarjana, I. M., \& Mahadewi, L. P. P. (2015). Analisis Penerapan Pendekatan Saintifik Terhadap Dalam Pembelajaran Berdasarkan Kurikulum 2013. MIMBAR PGSD Undiksha, 3(1).

Moleong. (2006). Metodelogi Penelitian Kualitatif. PT REMAJA ROSDAKARYA.

Muharmiati, M., Hermita, N., \& Guslinda. (2020). Analisis Penerapan Pendekatan Saintifik Dalam Kurikulum 2013 Di Kelas V SD Negeri 13 Pekanbaru Meri Muharmiati*, Neni Hermita, Guslinda Pendidikan Guru Sekolah Dasar FKIP Universitas Riau. Jurnal Penelitian Ilmu Pendidikan, 3, 104-113.

Nugraheni, E. P. (2019). Implementasi Kurikulum 2013 Pada Pembelajaran PAI Siswa Tunagrahita ( Studi Kasus Siswa Tunagrahita Sedang Kelas VII di SLB N 2 Yogyakarta ) 1. X(2), 140-150.

Nurbaya, Hala, Y., Hartati, Wiharto, M., \& Daud, F. (2018). Hubungan Pendekatan Saintifik dan Motivasi Belajar dengan Hasil Belajar. UNM Journal of Biological Education, 1(i).

Nurdyansyah, \& Fahyuni, E. F. (2016). Inovasi Model. In Nizmania Learning Center.

Pangandosan, A. (2018). Implementasi Pendekatan Saintifik Pada Kelas Rendah Di SD Negeri 1 Rawalaut Bandar Lampung. Society, 14-18.

Persada, Y. I., Djatmika, E. T., \& Degeng, I. N. S. (2020). Pelaksanaan Pendekatan Scientific Dalam Pembelajaran Tematik. 114-120.

Pujiyanto, P. (2013). Naskah Publikasi Pengelolaan Kurikulum dan Pembelajaran 2013 Sekolah Dasar (Studi Situs Di SD Hj. Isriati Baiturrahman 1 Semarang). Universitas Muhammadiyah Surakarta.

Rini Kristiantari, M. (2015). Analisis Kesiapan Guru Sekolah Dasar dalam Mengimplementasikan Pembelajaran Tematik Integratif Menyongsong Kurikulum 2013. JPI Uurnal Pendidikan Indonesia), 3(2), 460-470. https://doi.org/10.23887/jpi-undiksha.v3i2.4462

Rostika, D \& Zulkarnain, W. (2016). Analisis Implementasi Kurikulum 2013 dengan Sistem Kredit Semester. Manajemen Pendidikan, 25(2), 191-199.

Rudyanto, H. E. (2016). Model Discovery Learning Dengan Pendekatan Saintifik Bermuatan Karakter Untuk Meningkatkan Kemampuan Berpikir Kreatif. Premiere Educandum : Jurnal Pendidikan Dasar Dan Pembelajaran, 4(01), 41-48. https://doi.org/10.25273/pe.v4i01.305

Said, I. M., Sutadji, E., \& Sugandi, M. (2019). Pengembangan Bahan Ajar Berbasis Cooperative Learning Dengan Pendekatan Saintifik Untuk Siswa Smk Se-Kota Malang Program Keahlian Teknik Ototronik. Jurnal Pendidikan: Teori, Penelitian Dan Pengembangan, 1(2), 265-270. https://doi.org/http://dx.doi.org/10.17977/jp.v1i2.6131 
Subadi, T., Priyono, K. D., Dahroni, \& Musyiyam, M. (2013). Implementasi Pembelajaran IPS Berbasis Kurikulum 2013 Melalui Lesson Study Di Sekolah Muhammadiyah Kartasura. WARTA, 18(1), 62-76. https://doi.org/https://doi.org/10.23917/warta.v18i1.1168

Sugiyanto, S., Kartowagiran, B., \& Jailani, J. (2015). Pengembangan Model Evaluasi Proses Pembelajaran Matematika Di SMP Berdasarkan Kurikulum 2013. Jurnal Penelitian Dan Evaluasi Pendidikan, 19(1), 82-95. https://doi.org/10.21831/pep.v19i1.4558

Ula, F. (2015). Implementasi Pendekatan Saintifik Pada Kelas 1 Di SDN Mergosono 3 Kecamatan Implementasi Pendektan Saintifik Pada Pembelajaran Kurikulum 2013 Tema 7 Subtema 5.

Wahyuni, S., \& Kurniawan, T. (2019). Analisis Pelaksanaan Kurikulum 2013 Pada Mata Pelajaran Ekonomi SMA Berakreditasi A Di Kota Solok (Studi Kasus Pada SMA N 4 Solok). Jurnal EcoGen, 2(22), 706-714.

Wakhidah, F. N. H. (2019). Implementasi pembelajaran matematika dengan pendekatan saintifik di mi murni sunan drajat lamongan. Universitas Islam Negeri Maulan Malik Ibrahim.

Yanwar, A., \& Fadila, A. (2019). Analisis Kemampuan Berpikir Kritis Matematis : Dampak Pendekatan Saintifik ditinjau dari Kemandirian Belajar. Desimal: Jurnal Matematika, 2(1), 9-22. https://doi.org/10.24042/djm.v2i1.3204

Yeti. (2017). Dalam Pembelajaran Bahasa Arab Di Kelas X Man Purwokerto 2. Journal IAN.

Yustitia, V., Rusminati, S. H., \& Sulistyawati, I. (2018). Penerapan model think pair share dengan pendekatan saintifik melalui lesson study pada mata kuliah evaluasi pembelajaran SD. Premiere Educandum: Jurnal Pendidikan Dasar Dan Pembelajaran, 8(1), 88. https://doi.org/10.25273/pe.v8i1.2621

Zaman, Q. (2017). Implementasi Pendekatan Saintifik Kurikulum. Universitas Islam Negeri Maulana Malik Ibrahim. 